\title{
Properties, processes and modes characterizing the state of heavy metals in soils
}

\author{
Andrey Sorokin ${ }^{1}$, Sergey Belopukhov ${ }^{2}$, Vladimir Gukalov ${ }^{3}$, Vitaly Savich ${ }^{2}$, Ravil \\ Baibekov $^{2}$, and Nikolay Tyutrin, ${ }^{4}$, \\ ${ }^{1}$ Moscow Aviation Institute, 125993 Moscow, Russia \\ ${ }^{2}$ Russian State Agrarian University-Moscow Timiryazev Agricultural Academy, Moscow, 127550 \\ Moscow, Russia \\ ${ }^{3}$ Kuban State Agrarian University, 350044 Krasnodar, Russia \\ ${ }^{4}$ Irkutsk national research technical University, 664074 Irkutsk, Russia
}

\begin{abstract}
The study proves the expediency of assessing the state of heavy metals in soils by the fractional composition of soil compounds, processes and modes. An informational and energy analysis of the state of heavy metals in soils was carried out. The need for an assessment of the kinetics of their desorption from soils was substantiated. The $\mathrm{CH}_{3} \mathrm{COONH}_{4}$ solution displaced $0.3 \mathrm{mg} / \mathrm{l} \mathrm{Mn}$ from the sod-podzolic soil within 10 minutes, $0.8 \mathrm{mg} / \mathrm{l} \mathrm{Mn} \mathrm{-} \mathrm{within} 1$ hour, $3.3 \mathrm{mg} / \mathrm{l} \mathrm{Mn} \mathrm{-} \mathrm{within} 1$ day, and $12.9 \mathrm{mg} / \mathrm{l}$ - within one week; $0.18 \mathrm{mg} / \mathrm{L} \mathrm{Pb}$ was desorbed within 10 minutes, up to $0.59 \mathrm{mg} / \mathrm{l} \mathrm{Pb}$ was desorbed within one day. The depositing capacity of soils is an important parameter. Heavy metals in soils are bound into positively and negatively charged systems at $\mathrm{pKH}$ of 2-10. In the sod-podzolic soil, the content of $\mathrm{NiLn}^{+}$was $13.3 \mathrm{mg} / \mathrm{l}$ and NiLn- - 1.9 $\mathrm{mg} / \mathrm{l}$. According to the informational assessment, heavy metals in soils are characterized by the relationship with other soil properties and change along the soil profile, which was determined from the equations of pair correlation and multiple regression. According to the energy assessment, heavy metals in soils are characterized by thermal effects of their sorption and desorption and have positively and negatively charged complex compounds and air ions
\end{abstract}

\section{Introduction}

Contamination with heavy metals is a serious threat to the agricultural industry and human health [1]. Soil is the main receptor for heavy metals [2,3]. A description of the state of heavy metals in soils is of great agroecological importance. However, despite a significant number of studies, the state of metals has been rarely assessed by the content or ongoing processes and modes.

The study aims at assessing the state of heavy metals in soils by the kinetics factor, the depositing capacity of soils, the content of complex positively and negatively charged

\footnotetext{
* Corresponding author: tno73@yandex.ru
} 
compounds, taking into account the informational and energy characteristics of soil processes.

The object is sod-podzolic soils and chernozems, arable soils and soils of urban agglomerations [1,2]. The study aims to determine the bulk and mobile forms of heavy metals in soils, the depositing capacity of soils, the kinetics of sorption and desorption of heavy metals, the content of positively and negatively charged compounds and aeroions [3, $4,5]$. The probability level was $\mathrm{P}=0.95$.

It is promising to assess the state of heavy metals by their displacement from the soil, the depositing capacity of soils to heavy metals, the content of positively and negatively charged complex compounds displaced from the soil by the method of chemical electrolysis-based autography. The influence of heavy metals on the agroecological state of landscape components is determined by the rate of their transition from the soil to the solution. This process is described by the equations of intradiffusion and chemical kinetics of different orders. The higher the rate of transition of heavy metals from the soil to the solution, the greater the inhibitory effect they have on the landscape components, and the lower the MPC values. The kinetics of desorption processes is determined by the absorption capacity of soils, $\mathrm{pH}$, mineralogical and granulometric compositions, humus content, ionic strength of solutions, temperatures, and other parameters. This indicator is typical of some soils and horizons (Table 1).

Table 1. Kinetics of Mn Displacement from Soils (0,1n $\left.\mathrm{CH}_{3} \mathrm{COONH}_{4}\right), \mathrm{mg} / \mathrm{l}$

\begin{tabular}{|c|c|c|c|c|}
\hline \multirow{2}{*}{ Soil } & \multicolumn{3}{|c|}{ Content in solution at desorption time } \\
\cline { 2 - 5 } & 10 minutes & 1 hour & 1 day & 1 week \\
\hline sod-podzolic Ap & 0,3 & 0,8 & 3,3 & 12,9 \\
chernozem & 0,9 & 1,2 & 2,2 & 3,2 \\
Ap & 0,3 & 2,3 & 1,0 & 2,1 \\
AB & 0,1 & 2,2 & 0,4 & 0,8 \\
\hline
\end{tabular}

With an increase in the interaction time, the displacement of manganese from soils increases sharply. The degree of an increase in the desorption with an increase in the duration of interaction between the soils and the solution is characteristic of some soils and horizons. In this case, with an increase in the interaction time, different sorption sites are involved in the reaction, and the composition of the equilibrium solution changes. This can decrease the content of the desorbed ion in the solution and increase the duration of desorption, which is typical of chernozem. The kinetics of desorption was also observed for lead whose content was $0.18-0.20 \mathrm{mg} / \mathrm{l}$ during the 10-minute desorption, and 0.47-0.59 $\mathrm{mg} / \mathrm{l}$ - during the one-day interaction of the soil and the solution.

To assess the kinetics of desorption processes, it is promising to calculate the ratio of maximum and minimum concentrations of the displaced ion for long and short interaction periods. With an interaction time of one week and 10 minutes, the ratio of the lead content in the desorbent $\mathrm{CH}_{3} \mathrm{COONH}_{4}$ solution was 5.8 for heavy loamy chernozems; 3.6. - for light loamy soils; 2.6 - for sod-podzolic soils; 12.3 - for urban soils of Moscow. For zinc, these indicators were equal to $5.5 ; 3.0 ; 1.2$ and 1.5 , respectively.

The content of elements in the soil and the desorbent is determined by the solubility of their precipitates, effective constants of ion exchange and instability of the complexes. This indicator does not provide complete information on the content of mobile forms of elements in the solid phase of soils. To assess the total content of mobile forms of elements in soils, the depositing capacity of soils is determined when ions are displaced from the solid phase by the successive portions of desorbents. The depositing capacity of soils for $\mathrm{Pb}$ in the $\mathrm{H} 2 \mathrm{O}$ extract of $7.5 \mathrm{l} / 10 \mathrm{~g}$ was $0.5 \mathrm{mg} / 100 \mathrm{~g}$ for heavy loamy chernozems, and $0.2 \mathrm{mg} / 100 \mathrm{~g}$ for light loamy chernozems; in the lead-contaminated sod-podzolic soil, it was $1.1 \mathrm{mg} / 100 \mathrm{~g}$; 
for $\mathrm{Zn}$, it was 1.2 ; 0.6 and 2.0, respectively. The soils contain several heavy metals and their hydroxyl complexes.

The content and ratio of positively and negatively charged cation compounds in soils change with the application of organic fertilizers

Heavy metals in soils have different forms and bond strengths, including positively and negatively charged complex compounds with organic ligands (Table 2).

Table 2. Content of positively and negatively charged compounds of iron and nickel systems in sodpodzolic soils after the electrophoretic introduction of nickel, $\mathrm{mg} / \mathrm{l}$

\begin{tabular}{|c|l|r|r|r|}
\hline Section, horizon & $\mathrm{Fe}$ & $\mathrm{Ni}$ & \multicolumn{1}{l|}{} \\
\cline { 2 - 5 } & + & - & + & 13,3 \\
P-1 A & 2,4 & 4,8 & 6,9 & 3,5 \\
$\mathrm{~A}_{2}$ & 4,0 & 17,3 & 2,8 & 4,7 \\
$\mathrm{~A}_{2} \mathrm{~B}$ & 2,5 & 1,9 & 5,8 & 3,6 \\
$\mathrm{~B}_{1}$ & 3,3 & 0,9 & 2,1 & 4,2 \\
$\mathrm{~B}_{2}$ & 2,3 & 19,1 & 7,8 & 7,7 \\
P-2 A & 6,9 & 4,5 & 5,3 & 12,3 \\
$\mathrm{~A}_{2}$ & 2,5 & 3,5 & 19,9 & 6,9 \\
$\mathrm{~A}_{2} \mathrm{~B}$ & 3,8 & 16,4 & 3,2 & 5,2 \\
$\mathrm{~B}_{1}$ & 1,7 & 2,4 & 3,5 & 3,1 \\
$\mathrm{~B}_{2}$ & 3,3 & \multicolumn{3}{c}{} \\
\hline
\end{tabular}

*) $10 \mathrm{~g}$ of soil; $\varphi=12 \mathrm{v} ; \mathrm{t}=10 \mathrm{~min}$.

The sod-podzolic soils and chernozems contain complex positively and negatively charged compounds $\mathrm{Fe}, \mathrm{Mn}, \mathrm{Ca}, \mathrm{Zn}, \mathrm{Ni}, \mathrm{K}$, P. Soil saturation with $\mathrm{KH}_{2} \mathrm{PO}_{4}$ increased the share of postiviely charged $\mathrm{Ca}$ compounds, but decreased the share of positively charged compounds of zinc, iron, and calcium in the soils under study and $\mathrm{Ca}$ in the sod-podzolic soil. Soil saturation with nickel increased the share of mobile iron in the soil and slightly increased the share of positively charged iron compounds. Positive and negative compounds of $\mathrm{Ca}, \mathrm{Mg}, \mathrm{Fe}, \mathrm{Mn}, \mathrm{Zn}, \mathrm{Cu}, \mathrm{K}, \mathrm{Na}$ were found in the leaves of apple trees. At the same time, in $\mathrm{Ca}, \mathrm{Mg}, \mathrm{K}, \mathrm{Na}$, the share of positively charged compounds prevails; in $\mathrm{Fe}$ and $\mathrm{Mn}$, negatively charged compounds are dominant. It is necessary to assess the content and ratio of positively and negatively charged cation compounds in the soil-apple tree system in order to identify plant oppression causes.

According to the data obtained, complex compounds of heavy metals have different molecular weights and are characterized by different stability constants of the complexes. The negative logarithm of the instability constants for water-soluble organic soil substances, humic and fulvic soil acids with polyvalent cations $\mathrm{pC}_{\mathrm{H}}$ varied from 2 to 20 .

The fulvic acids have a higher ability to form complex compounds with heavy metals than the humic acids. The ability of organic ligands depends on the molecular weight of organic substances. With an acidic reaction of the medium, protonation was observed; with an alkaline reaction, the effect of hydrate formation was observed. Thus, in the water extract from the permafrost taiga soils, the Fe content was 2-27 mg/l. During the desorption of iron from the soils $2 \mathrm{~N} \mathrm{HC1}$ ( $\mathrm{t}=5$ minutes) before the destruction, $157.7 \mathrm{mg} / 100 \mathrm{~g}$ were displaced from $\mathrm{A}_{1}$; after the destruction, $796.2 \mathrm{mg} / 100 \mathrm{~g}$ were displaced. During the desorption of iron, $0.1 \mathrm{~N} \mathrm{KC1}+0.01 \mathrm{~m}$ EDTA were displaced at $\mathrm{pH}=4-30 \mathrm{mg} / 100 \mathrm{~g}$, and only 3.7 - at $\mathrm{pH}=8$.

To assess the ability of organic ligands of soil solutions to polyvalent metals, it is promising to determine an increase in the effective solubility of precipitates when the water-soluble organic substance is added to the desorbent.

According to the data obtained, the complexing ability of organic substances in relation to $\mathrm{Pb}(10-4 \mathrm{~m} / \mathrm{l})$ was 18.7 and 16.4 for humic and ulminic acids of the chernozem, respectively; for the humic and ulminic acids of the soddy-podzolic soil, it was 17.3 and 
$23.2 \mathrm{mg} / \mathrm{l}$, respectively. In relation to $\mathrm{Cu}$, the complexing ability of water-soluble organic substances of the meadow-chernozem and sod-podzolic soils was 2.2 and $2.2 \mathrm{mg} / \mathrm{l}$ at the optimal moisture content and 7.8 and $5.8 \mathrm{mg} / \mathrm{l}$ - with excess moisture, increasing with the introduction of $30 \mathrm{t} / \mathrm{ha}$ hay up to $6-8 \mathrm{mg} / \mathrm{l}$ or $175-670 \mathrm{mg} / \mathrm{g}$.

The state of heavy metals in soils is characterized by their content, processes and modes.

In case of contamination, the $\mathrm{pH}$ of the environment changes, and the microbiological activity is inhibited with an increase in the share of fungal microflora. This changes the processes of decomposition of plant residues and composition of water-soluble organic substances. The ongoing changes can take over the deeper layers of the soil profile.

The resulting changes in the soil properties change the state of heavy metals. In the leached chernozem, the activity of $\mathrm{NO}_{3} \mathrm{mg} / \mathrm{l}$ was $(11.45 \pm 0.9) 10^{-4}$ and $(0.83 \pm 0.1) 10^{-4}$ within 15 minutes and 3 days, respectively. When $\mathrm{Pb}(200 \mathrm{mg} / \mathrm{kg})$ was added to the soil, it was $(9.58 \pm 1.89) \cdot 10^{-4}$ and $(0.60 \pm 0.02) \cdot 10^{-4}$, respectively.

The regularities of sequential changes differ for different types and smaller taxonomic units of soils, hydrothermal conditions, and degrees of soil pollution.

In the chernozem, at optimal humidity values, the content of $\mathrm{Pb} \mathrm{mg} / \mathrm{l}$ was 0.01 and 0.09 within 1 day and 3 weeks, respectively; with excess humiduty values, it was 0.07 and 0.09 ; the content of $\mathrm{NO}_{3} \mathrm{mg} / \mathrm{l} \cdot 10^{-4}$ was 25.0 and 2.5 at optimum humidity values; with excess humudity values, it was 55.0 and 22.5 .

In the sod-podzolic soils containing $\mathrm{Pb}-200 \mathrm{mg} / \mathrm{kg}$, the content of $\mathrm{NO}_{3}$ was $(45.8 \pm$ 1.9) $10-4 \mathrm{mg} / \mathrm{l}$ within 15 minutes, $(12.6 \pm 2.6) \cdot 10^{-4}$ - within one day, $(0.8 \pm 0.1)^{10-4} \mathrm{mg} / \mathrm{l}-$ within three days. The $\mathrm{pH}$ value was $7.7 ; 8.1$ and 8.3 within 15 minutes, three days and six days, respectively; Eh was 473, 459 and $405 \mathrm{mV}$.

The content of heavy metals changes in the seasonal and long-term dynamics and depends on the level of water and air contamination with heavy metals. In the sod-podzolic soils of the Forest Experimental Dacha located $30 \mathrm{~km}$ away from the road, for 80-90 days, the lead content increased from 6 to $104 \mathrm{mg} / \mathrm{kg}$, the zinc content increased from 11.6 to $153.0 \mathrm{mg} / \mathrm{kg}$; the cadmium content increased from 0.04 to $0.74 \mathrm{mg} / \mathrm{kg}$. In the snow cover, the $\mathrm{Pb}$ content was $0.26 \mathrm{mg} / \mathrm{l}$, the Mn content was $0.28 \mathrm{mg} / \mathrm{l}$, the Fe content was $13.8 \mathrm{mg} / \mathrm{l}$; the $\mathrm{Pb}$ content was $0.52 \mathrm{mg} / \mathrm{l}$, the $\mathrm{Mn}$ content was $2.7 \mathrm{mg} / \mathrm{l}$; the Fe content was $32.2 \mathrm{mg} / \mathrm{l}$.

In ordinary chernozems of Krasnodar region, the linear character of long-term trends is described by the following equations: $\mathrm{Pb}=0.14 \mathrm{t}+1.42 ; \mathrm{R}^{2}=0.63 ; \mathrm{Cd}=0.003 \mathrm{t}+0.003 ; \mathrm{R}^{2}$ $=0.90 ; \mathrm{Co}=0.15 \mathrm{t}+0.499 ; \mathrm{R}^{2}=0.71$.

During the growing season, the content of gross and mobile forms changed to a much lesser extent. For mobile forms of $\mathrm{Pb}$, it changed from 4.2 to $4.4 \mathrm{mg} / \mathrm{kg}$; for $\mathrm{Cd}$ - from 0.07 to $0.08 \mathrm{mg} / \mathrm{kg}$; for $\mathrm{Ni}$ - from 6.5 to $7.1 \mathrm{mg} / \mathrm{kg}$; for Co - from 3.3 to $3.8 \mathrm{mg} / \mathrm{kg}$. The content of Mn changed from 212 to $241 \mathrm{mg} / \mathrm{kg}$.

Under the anthropogenic contamination, the gross content of heavy metals in soils decreases along the soil profile. This dependence is more pronounced for accumulative relief elements. For ordinary chernozems (on plateaus and in accumulative releif elements), the change in the nickel content can be described by the equation: $\mathrm{Y}=54.6-0.04 \mathrm{H} \mathrm{cm}, \mathrm{r}=$ -0.75 and $\mathrm{Y}=71.2-0.43 \mathrm{H} \mathrm{cm} ; \mathrm{r}=-0.90$; for $\mathrm{Pb}-\mathrm{Y}=20.1-0.02 \mathrm{~N} \mathrm{~cm}, \mathrm{r}=-0.72$ and $\mathrm{Y}=$ $27.4-0.14 \mathrm{~N} c \mathrm{c} ; \mathrm{r}=-0.86$; for $\mathrm{Zn}-\mathrm{Y}=76.9-0.09 \mathrm{~N} \mathrm{~cm} ; \mathrm{r}=-0.93$ and $\mathrm{Y}=94.3-0.58 \mathrm{~N}$ $\mathrm{cm} ; \mathrm{r}=-0.87$.

The content of mobile forms of heavy metals in soils depends on the distance of sampling points from the source of contamination. In the center of the Forest Dacha of Moscow Agricultural Academy, the lead content was $62-86 \mathrm{mg} / \mathrm{kg}$; near the mainline, it was $114-139 \mathrm{mg} / \mathrm{kg}$. At the same time, soil contamination with heavy metals depends on the wind rose, wind speed, and air permeability of tree plantations. 
The degree of contamineation is different for different tree plantations. In the center of the forest park, under the pine-birch phytocenosis, the zinc content was $96 \mathrm{mg} / 100 \mathrm{~g}$; at the border with the city, it was $211 \mathrm{mg} / 100 \mathrm{~g}$. The degree of contamination does not always depend on the distance from the source of contamination. It increases in granulometric soils and low relief elements with an increase in the intensity of the soddy process of soil formation, compaction, and gleying.

With an increase in the content of heavy metals in soils, they turn into evaporation products from soils and transpiration products from plants. The content of heavy metals in the products of evaporation from soils was as follows: $\mathrm{Pb}-0.1-0.2 \mathrm{mg} / \mathrm{l} ; \mathrm{Fe}-0.2-0.8 \mathrm{mg} / \mathrm{l}$; $\mathrm{Zn}-0.04-0.10 \mathrm{mg} / \mathrm{l} ; \mathrm{Cu}-0.04-0.10 \mathrm{mg} / \mathrm{l}$. Near the highway, the lead content in the evaporation products from the soil increased from 0.11 to $0.18 \mathrm{mg} / \mathrm{l}$; under heavy contamanitation, it increased up to $1.1 \mathrm{mg} / \mathrm{l}$. In transpiration products from plants, the $\mathrm{Pb}$ content was $0.11-0.28 \mathrm{mg} / \mathrm{l}$; the $\mathrm{Cu}$ content was $0.02-0.20 \mathrm{mg} / \mathrm{l}$; the $\mathrm{Pb}$ content was up to $0.25 \mathrm{mg} / \mathrm{l}$; the $\mathrm{Cu}$ content increased up to $0.25 \mathrm{mg} / \mathrm{l}$.

The content of heavy metals in surface waters and rivers depends on the amount of precipitation, the seasonal dynamics of agricultural practices and changes in the soil properties and the state of heavy metals in soils. In the summer period, the content of heavy metals in the river water $\left(\mathrm{mg} / \mathrm{dm}^{3}\right)$ at a distance of one $\mathrm{km}$ in front of and behind the village was as follows: $\mathrm{Zn}-0.017$ and 0.03 ; Mn 0.086 and $0.126 ; \mathrm{Pb}-0.006$ and 0.008 . In summer, the concentration of heavy metals in water increased: Co - from 0.002 to $0.004 \mathrm{mg} / \mathrm{dm}^{3} ; \mathrm{Zn}$ - from 0.012 to $0.024 ; \mathrm{Cu}$ - from 0.004 to 0.007 ; $\mathrm{Mn}$ - from 0.09 to $0.15 ; \mathrm{Pb}$ - from 0.007 to 0.009. Of great agroecological importance is the content of mobile forms of heavy metals and their assimilable forms, which depends on a combination of soil properties, sorption properties of the root systems of plants and hydrothermal conditions. The correlation of mobile forms of heavy metals with humus was $+0.84 \pm 0.08$ for $\mathrm{Co} ;+0.59 \pm 0.12$ for $\mathrm{Zn}$; $+0.71 \pm 0.11$ for $\mathrm{Cu} ;+0.79 \pm 0.09$ for $\mathrm{Mn} ; 0.64 \pm 0.11$ for $\mathrm{Pb} ;+0.74 \pm 0.10$ for $\mathrm{Cd} ;+0.80$ \pm 0.9 for Ni. The correlation of the mobile forms of heavy metals with the content of mobile forms of phosphates was significant. It amounted to $0.65 \pm 0.1$ for Co; $0.55 \pm 0.12$ for $\mathrm{Zn} ; 0.73 \pm 0.10$ for $\mathrm{Cu} ; 0.67 \pm 0.11$ for $\mathrm{Mn} ; 0.57 \pm 0.12$ for $\mathrm{Pb} ; 0.45 \pm 0.13$ for $\mathrm{Cd} ; 0.59$ \pm 0.12 for $\mathrm{Ni}$. At the same time, the correlation of the content of mobile forms of heavy metals with $\mathrm{pH}$ was negative. It was $0.29-0.28$ for $\mathrm{Co}, \mathrm{Zn}, \mathrm{Cu}$; for $0.20 \mathrm{Mn}$; $0.40-0.46$ for $\mathrm{Pb}, \mathrm{Cd}, \mathrm{Ni}$. Information is also provided by the regression models of dependences of the concentrations of mobile forms of metals on soil properties. The dependence on the humus content for chernozems was described by the following equations: $\mathrm{Pb}=1.47+0.92 \mathrm{G} ; \mathrm{R}^{2}=$ $0.92 ; \mathrm{Cd}=0.01+0.01 \mathrm{G} ; \mathrm{R}^{2}=0.90 ; \mathrm{Co}=0.26+0.9 \mathrm{G} ; \mathrm{R}^{2}=0.93 ; \mathrm{Ni}=1.6+1.16 \mathrm{G} ; \mathrm{R}^{2}=$ 0.93 (metal content in $\mathrm{mg} / \mathrm{kg}$, humus, \%).

The content of water-soluble forms of heavy metals $\left(\mathrm{X}_{1}\right)$ often correlates with the content of their mobile forms $\left(\mathrm{X}_{2}\right)$ and does not always correlate with the content of acidsoluble forms $\left(\mathrm{X}_{3}\right)$ and gross content. The following regression equations were obtained for the soils of the megalopolis park: for $\mathrm{Ni}, \mathrm{X}_{1}=0.006 \mathrm{X}_{2}-0.001 \mathrm{X}_{3}+0.077$; for $\mathrm{Pb} \mathrm{X}_{1}=$ $0.026 \mathrm{X}_{2}-0.000 \mathrm{X}_{3}+0.107$. With a certain degree of approximation, the sorption of heavy metals by soils and their desorption from the soils were described by the Freudlich equation: $\lg \mathrm{Pb}=\lg \mathrm{K}+1 / \mathrm{n} \lg \mathrm{X}$ with several different stages of sorption and desorption.

The dependences of the content of mobile forms of heavy metals on the soil properties differ for soils located in different relief elements. The dependence of the content of mobile forms of heavy metals on soil properties was described by the following equations (humus $\left.\mathrm{X}_{1},<0.01 \mathrm{~mm}-\mathrm{X}_{2} \cdot \mathrm{NO}_{3}-\mathrm{X}_{3}, \mathrm{NH}_{4}-\mathrm{X}_{4}, \mathrm{P}_{2} \mathrm{O}_{5}-\mathrm{X}_{5}\right)$. As can be seen from Table 3, the relationship between the content of mobile lead compounds and soil properties differs for different elements of the catena. In the gully soils, the dependence of the content of mobile lead compounds on the content of humus $\left(-0.3 \mathrm{X}_{2}\right), \mathrm{NO}_{3}-\left(+0.5 \mathrm{X}_{3}\right), \mathrm{NH}_{4}\left(-0.3 \mathrm{X}_{4}\right)$ is greater than in other relief elements. All the soils are characterized by a positive 
relationship between the content of mobile forms of lead and the content of mobile phosphates.

Table 3. The dependence of the content of mobile lead in ordinary chernozems in different elements of the mesorelief on the soil properties

\begin{tabular}{|l|l|l|r|}
\hline Relief element & Regression equation & r & \multicolumn{1}{|c|}{} \\
\hline southern watershed & $\mathrm{Pb}=-2,8+0,8 \mathrm{X}_{1}+0,05 \mathrm{X}_{2}-0,3 \mathrm{X}_{3}+0,3 \mathrm{X}_{4}+0,1 \mathrm{X}_{5}$ & 0,85 & 2,2 \\
northern watershed & $\mathrm{Pb}=6,2+0,2 \mathrm{X}_{1}-0,04 \mathrm{X}_{2}-0,02 \mathrm{X}_{3}-0,01 \mathrm{X}_{4}+0,03 \mathrm{X}_{5}$ & 0,96 & 9,5 \\
south slope & $\mathrm{Pb}=6,4-0,2 \mathrm{X}_{1}-0,02 \mathrm{X}_{2}-0,02 \mathrm{X}_{3}-0,04 \mathrm{X}_{4}+0,1 \mathrm{X}_{5}$ & 0,68 & 6,6 \\
north slope & $\mathrm{Pb}=1,6+0,1 \mathrm{X}_{1}+0,04 \mathrm{X}_{2}-0,06 \mathrm{X}_{3}-0,03 \mathrm{X}_{4}+0,06 \mathrm{X}_{5}$ & 0,90 & 3,5 \\
beam & $\mathrm{Pb}=24,9-0,2 \mathrm{X}_{1}-0,3 \mathrm{X}_{2}+0,5 \mathrm{X}_{3}-0,3 \mathrm{X}_{4}+0,01 \mathrm{X}_{5}$ & 0,99 & 138,4 \\
\hline
\end{tabular}

As can be seen from Table 4, in chernozems, due to the intensive development of the sod process, the content of heavy metals decreases more sharply in the $60-80 \mathrm{~cm}$ layer as compared to the $0-20 \mathrm{~cm}$ layer. The distribution of heavy metals along the soil profile is determined by soil-forming processes (Table 4).

Table 4. Gross content of heavy metals along the soil profile of Tuva, $\mathrm{mg} / \mathrm{kg}$

\begin{tabular}{|ll|c|c|c|c|}
\hline Soil layer & & $\mathrm{Cu}$ & $\mathrm{Zn}$ & $\mathrm{Cd}$ & $\mathrm{Pb}$ \\
\hline chernozem & $0-20$ & 21,2 & 41,7 & 0,58 & 20,2 \\
& $60-80$ & 18,4 & 31,5 & 0,42 & 14,1 \\
Light brown & $0-20$ & 11.3 & 34,5 & 0,23 & 10,7 \\
& $60-80$ & 12,5 & 30,1 & 0,21 & 8,9 \\
\hline
\end{tabular}

According to L.V. Mosina, in the soils of the Forest experimental dacha, the entire root layer to a depth of one m contains a significant amount of heavy metals (2.6-4 times higher than Clarke). The first maximum accumulation of heavy metals was observed in $\mathrm{A}_{1}$ layer, the second - in B horizon. Even at a depth of $70-100 \mathrm{~cm}$, the lead content varied from 12 to $42 \mathrm{mg} / \mathrm{kg}$. To assess this, dry soil sifting was carried out, and the content of HMs in different layers was determined (after freezing and removing the layers or after successive removal of layers with an adhesive tape). Soil grinding and coagulation with water-soluble organic substances of plant residues $+\mathrm{Ca}, \mathrm{Mg}$ help to create a soil structure.

The energy state of heavy metals in soils is characterized by thermal effects of their sorption by different types of soils and horizons. The difference in soil temperatures during the absorption of $\mathrm{H}_{2} \mathrm{O}$ and $0.1 \mathrm{n} \mathrm{Pb}\left(\mathrm{NO}_{3}\right) 2$ was +0.60 for the arable layer of sod-podzolic soils, and +1.10 - for ordinary chernozems. For different soil horizons, it changed from 0.20 to $+0.2-1.10$. The energy state of heavy metals in soil vapor was determined by the content of air ions. The content of positively and negatively charged air ions in the vapor from ordinary chernozems was as follows: positively charged ions $-0.09 \cdot 10^{-3}$, negatively charged ions $-0.17 \cdot 10^{-3}$; in the soil contaminated with lead, the content of positively and negatively charged air ions was $0.16 \cdot 10^{-3}$ and $0.05 \cdot 10^{-3}$, respectively. In the degraded chernozems and the soil contaminated with lead, the content was as follows : positively charged ions $-0.14 \pm 0.04$ and $0.06 \pm 0.01$; negatively charged ions $-0.13 \pm 0.04$ and $0.07 \pm$ $0.01\left(\mathrm{a} \cdot 10^{-3}\right)$. The unipolarity coefficients for uncontaminated and lead-contaminated chernozems were $2.0 \pm 0.4$ and $4.5 \pm 1.3$, respectively.

Thus, the study has shown the feasibility of assessing the state of heavy metals in soils by their properties, ongoing processes and modes, by transformation, migration and accumulation of susbstances, energy and information. The change in the state of heavy metals in soils is interrelated with their state in water and air, plants and microorganisms. An assessment of the state of heavy metals in soils by the rate of transition from the soil to the desorbent solution, the depositing ability of soils, the content of positively and 
negatively charged complex compounds, the mathematical laws of relationships with soil properties and their changes in time and space was carried out.

\section{References}

1. Zhang, X., Kumstel, S., Tang, G., Talbot, S.R., Seume, N., Abshagen, K., Vollmar, B., Zechner, D. // Altex. Volume 37, Issue 2, March 2020, Pages 197-207.

2. Youyuan Shao, Tao Yan, Kai Wang, Simin Huang, Wuzhi Yuan, Frank G.F. Qin. // 7th International Conference on Energy and Environment Research, ICEER 2020, 14-18 September, ISEP, Porto, Portugal. Energy Reports. Volume 6, Supplement 8, December 2020, Pages 122-127

3. Renji Zheng, Xuezhen Feng, Wensong Zou, Ranhao Wang, Dazhong Yang, Wenfei Wei, Shangying Li, Hong Chen. // Journal of Hazardous Materials. Volume 412, 15 June 2021, 125199

4. Han Xiao, Jürgen Böttcher, Jens Utermann. // Geoderma. Volumes 241-242, March 2015, Pages 115-125

5. Zhenyu Liu, Huiqin Guo, Huan He, Cheng Sun. // Journal of Environmental Sciences. Volume 24, Issue 3, March 2012, Pages 427-434. 